\title{
Depositional environment of Stelloglyphus llicoensis isp. nov.: a new radial trace fossil from the Neogene Ranquil Formation, south-central Chile
}

\author{
Jacobus P. Le Roux ${ }^{1}$, Sven N. Nielsen², Álvaro Henríquez ${ }^{1}$
}

\author{
I Departamento de Geología, Facultad de Ciencias Físicas y Matemáticas, Universidad de Chile, Casilla 13518, Correo 21, \\ Santiago, Chile. \\ jroux@cec.uchile.cl; ahenriquez@cec.uchile.cl \\ 2 Institut für Geowissenschaften, Christian-Albrechts-Universität, Ludewig-Meyn-Str.10, 24118 Kiel, Germany. \\ nielsen@gpi.uni-kiel.de
}

\begin{abstract}
Stelloglyphus llicoensis isp. nov. is a large radial, discoidal to ellipsoidal trace fossil with a central shaft and single to bifurcating branches radiating from different levels. A $30 \mathrm{~m}$ thick measured section of the Ranquil Formation at Punta Litre contains an associated trace fossil assemblage including Zoophycos, Chondrites, Phycosiphon, Nereites missouriensis, Lockeia siliquaria, Psammichnites(?), Parataenidium, Ophiomorpha, and Rhizocorallium, some of which reworked the Stelloglyphus traces. The sedimentology, together with micro- and macrofossils and the associated trace fossil assemblage, suggest that the succession was deposited in an outer continental shelf to slope environment in subtropical to tropical waters.
\end{abstract}

Keywords: Continental shelf, Slope, Radial trace fossil, Ichnofacies, Stelloglyphus, Dactyloidites.

RESUMEN. Ambiente depositacional de Stelloglyphus llicoensis isp. nov.: una nueva traza fósil radial de la Formación Ranquil (Neógena), centro-sur de Chile. Stelloglyphus llicoensis isp. nov. es una traza fósil grande, radial, y discoidal a elipsoidal con una asta central y ramas sencillas a bifurcadas que radian desde diferentes niveles. Un perfil estratigráfico de 30 m medido en la Formación Ranquil en Punta Litre contiene una asociación de trazas fósiles asociadas que incluye Zoophycos, Chondrites, Phycosiphon, Nereites missouriensis, Lockeia siliquaria, Psammichnites(?), Parataenidium, Ophiomorpha, y Rhizocorallium, algunas de las cuales retrabajaron las trazas de Stelloglyphus. La sedimentología, junto con los micro- y macrofósiles y la asociación de trazas fósiles, indican que la sucesión fue depositada en la parte exterior de la plataforma continental hasta el talud continental en aguas subtropicales a tropicales. 


\section{Introduction}

The Ranquil Formation, south of Concepción, is equivalent to the Navidad Formation of central Chile in sedimentology, faunal content, age, and depositional history (Finger et al., 2007), but well separated geographically. It consists of fine conglomerates, sandstones, siltstones and mudstones (García, 1968) reflecting different environments (Nielsen et al., 2004; Nielsen and Frassinetti, 2007a; Finger et al., 2007). Besides the well known mollusk fauna, trace fossils are also ubiquitous and, although less studied, are common in both the Navidad (Encinas et al., 2006) and Ranquil Formations. Since trace fossils are known to be an excellent tool for reconstructing paleoenvironments, they are employed here as an additional means to determine the paleobathymetry, supplementing the microfossil data from nearby outcrops provided by Finger et al. (2007).

Trace fossils are generally visible only on bedding planes or in cross sections, so that they can normally be examined in two dimensions only. Three-dimensional studies are sometimes possible due to the removal of softer, surrounding deposits, for example where sand-filled galleries of Ophiomorpha or Thalassinoides within mudrocks are accentuated by erosion of the latter. Here we describe a new radial trace fossil, perfectly preserved in calcareous concretions that were eroded from their sedimentary host rocks and washed up on a beach east of Llico, south-central Chile. This provides a unique opportunity to study the morphology of this new ichnospecies in 3 dimensions.

\section{Geological Setting}

The radial trace fossil occurs in the Ranquil Formation of the Arauco Basin, which forms part of a series of basins developed along the Chilean continental margin (Aguirre, 1985; Le Roux and Elgueta, 1997). The basin is filled by Upper Cretaceous to Pleistocene deposits represented by the Maastrichtian Quiriquina Formation, the Paleogene Lebu Group, the Neogene Ranquil, Tubul and Albarrada formations, and younger, unconsolidated Holocene sediments (Pineda, 1986).

The Ranquil Formation, as originally defined by García (1968), crops out locally along the coast between Punta Millongue ( $\left.73^{\circ} 38^{\prime} \mathrm{W}-37^{\circ} 33^{\prime} \mathrm{S}\right)$ in the south and Punta Pichicui $\left(73^{\circ} 27^{\prime} \mathrm{W}-37^{\circ} 12^{\prime}\right.$ 'S) in the north (Fig. 1). Tavera (1942) proposed a Miocene age for this formation on the basis of echinoderm fossils. Groves and Nielsen (2003), based on unpublished foraminiferal data of $\mathrm{M}$. Marchant (personal communication to SNN, 2001) and supported by molluscan faunal similarities with the Navidad Formation in the coastal sector west of Santiago, suggested a Tortonian age for this formation. Finger et al. (2007) recorded the presence of the planktonic foraminifers Neogloboquadrina continuosa (N4b-N16), Globoquadrina dehiscens (N4b-N17), Globigerinella obesa s.1. (since P22), Globoturborotalia apertura (N16-N21), Neogloboquadrina acostaensis (N16-N23), Globorotalia spheriomiozea (N18-N19a), and Globorotalia puncticulata (N19a-N21) from the Ranquil Formation at Punta El Fraile (their locality FRA), $5 \mathrm{~km}$ east of the beach where the trace fossils were subsequently discovered. The overlapping range of these species confirms a Zanclean age (N19a) of 4.4 to 4.6 Ma, which we accept. Benthic foraminifers include Bulimina spicata, Pullenia bulloides, Ammodiscus discoideus, Ehrenbergina fyfei, Pyrgo murrhina, Sphaeroidina bulloides, Bathysiphon spp., and Melonis pompilioides, which suggest downslope mixing of shelf and bathyal species (Finger et al., 2007). The presence of the gastropods Zonaria frassinetti and Solatisonax bieleri in nearby outcrops of similar age indicates subtropical to tropical water temperatures (Groves and Nielsen, 2003; Nielsen and Frassinetti, 2007b). This is supported by the occurrence of the foraminifer Pulleniatina primalis (Kennett and Srinivasan, 1983). However, deep-water gastropod genera living today off the Chilean coast, e.g., Bathybembix, have also been reported from Punta El Fraile (Nielsen et al., 2004).

At the base of the Ranquil Formation, a unit consisting of intercalated shale and finegrained sandstone, overlain by paraconglomerates containing fine-grained sandstone and siltstone clasts within a clayey to silty matrix, can be distinguished. It is followed by grey mudstones intercalated with fine-grained, calcareous, welllaminated sandstones containing abundant plant material and calcareous concretions, as well as fluid escape structures. Hummocky cross-lamination was observed at some localities. This unit fines upward into poorly exposed mudrocks with calcareous 


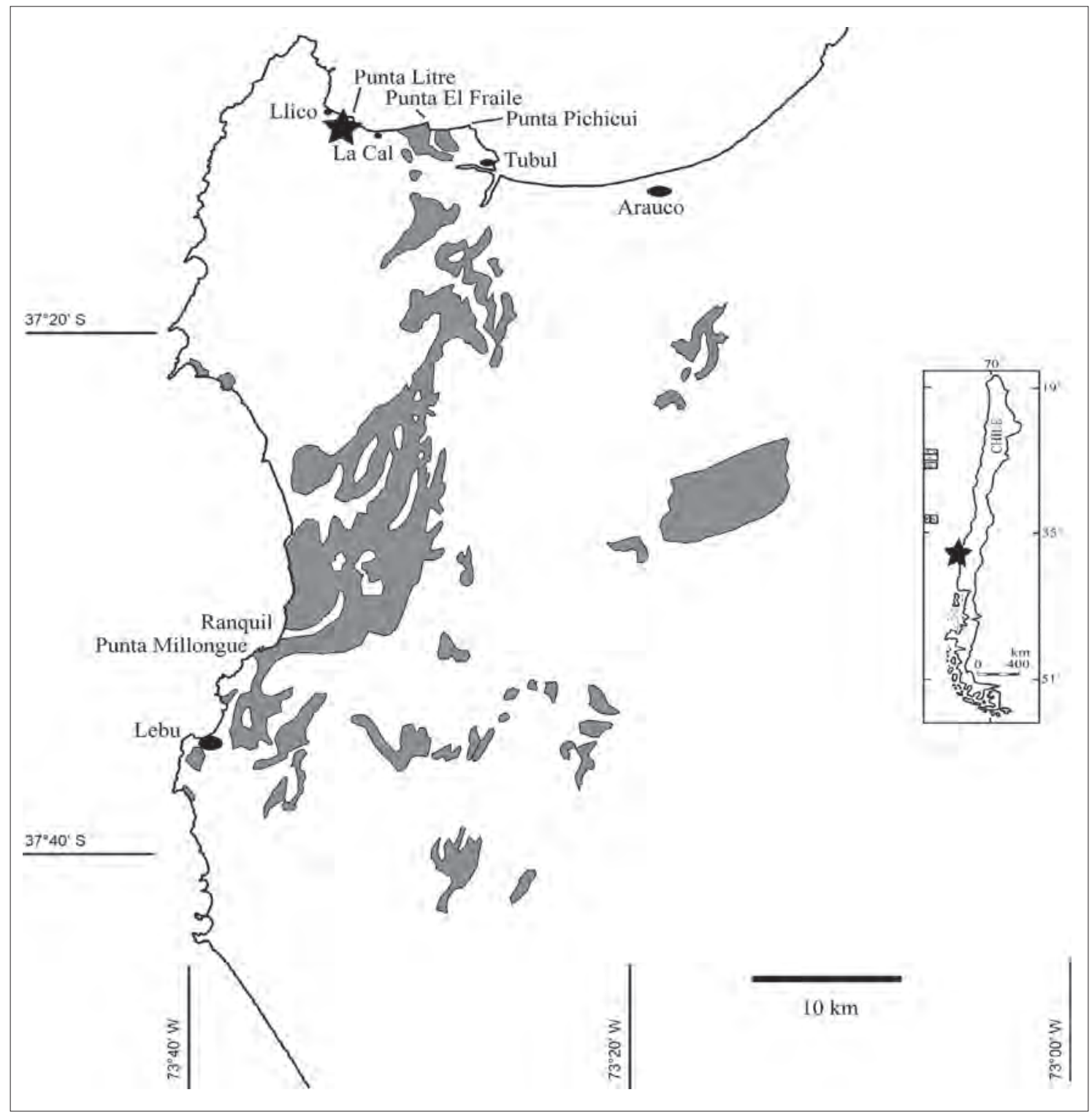

FIG. 1. Location map showing distribution of the Ranquil Formation on the Arauco Peninsula and localities mentioned in text. Star marks the type locality of Stelloglyphus llicoensis isp. nov.

concretions (containing the trace fossils described here), which are locally interbedded with mudstone breccias. In some areas (for example, Ranquil and Punta El Fraile) the mudrocks are deeply eroded by channels filled with medium- to very coarse-grained sandstone containing abundant mudstone clasts, interpreted by Le Roux et al. (2008) as resulting from a tsunami backwash which eroded coastal beach sand and dunes and redistributed them over the continental shelf and slope. Sandstone dykes penetrating the mudrocks from above are common at these localities (Le Roux and Vargas, 2005; Le Roux et al., 2008).

The greatest concentration of trace fossilbearing concretions occurs on the beach between Estero Pajonal and Punta Litre (37'11'43.80'S-

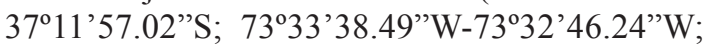
Fig. 1). At this locality, there is a beach cliff composed of mudrocks with in situ calcareous concretions (Fig. 2), some of which contain the radial trace fos- 


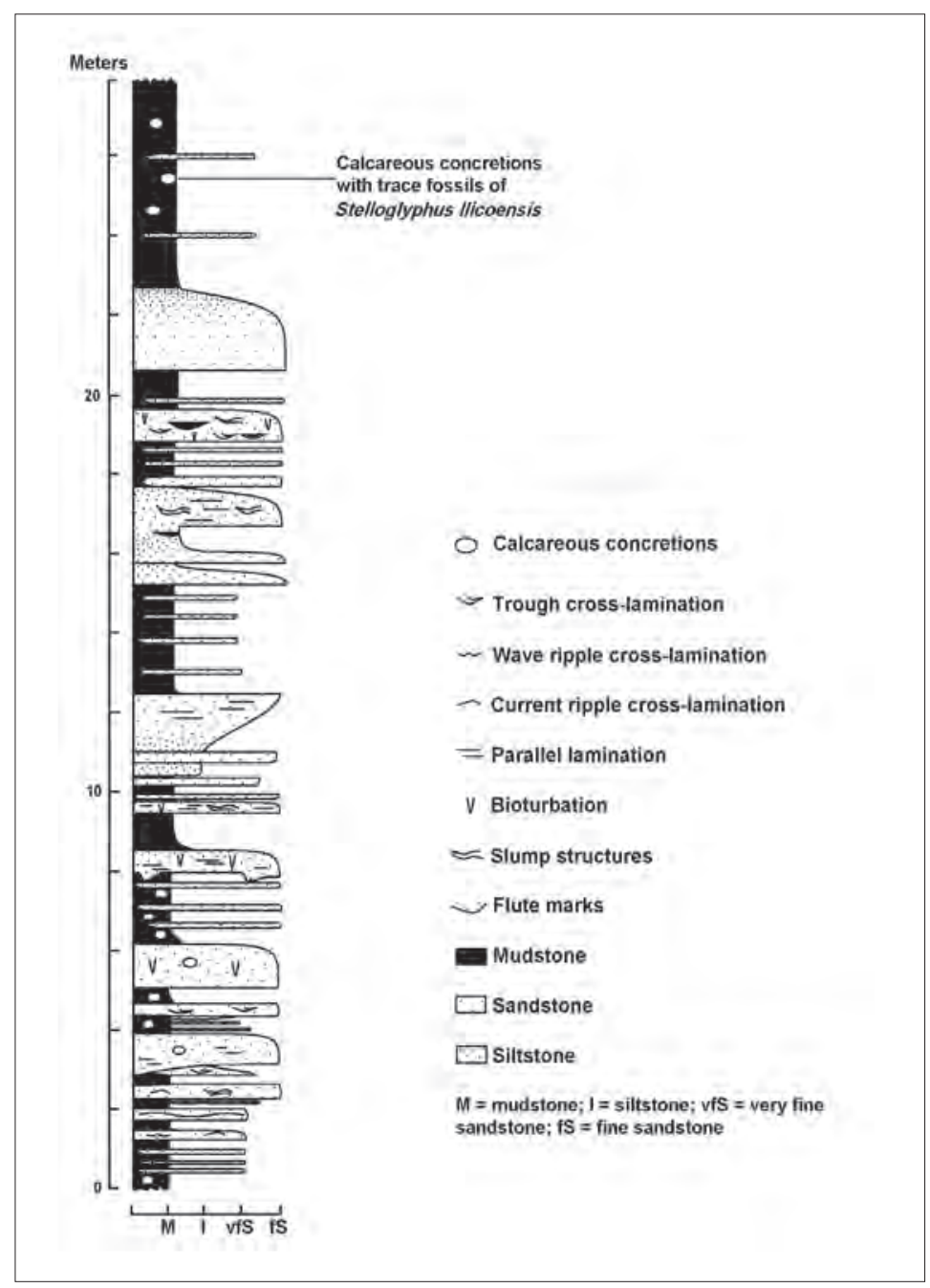

FIG. 2. Measured section of the Ranquil Formation between Punta Litre and Estero Pajonal.

sils (Fig. 3). It is very unlikely that these concretions could have been reworked from older beds, because the mudstones in which they occur represent a very low-energy environment where currents would have been incapable of transporting them.

The beds in this section dip gently westward, so that the measured section at Punta Litre (Fig. 2) depicts the immediately underlying succession of intercalated mudstones and fine- to very fine-grained sandstones. The latter show parallel lamination, current and wave ripple lamination, small-scale trough cross-lamination, as well as flute, slump and fluid escape structures.

Trace fossils are fairly common in the interbedded sandstone-mudstone unit and include
Zoophycos, Chondrites, Phycosiphon, Nereites missouriensis, Lockeia siliquaria, Parataenidium, Ophiomorpha, Rhizocorallium and Psammichnites(?). Because the last ichnogenus is known only from the Paleozoic, the traces could alternatively represent Scolicia.

The Zoophycos ichnofacies seems to best represent the trace fossil assemblage mentioned above. In Seilacher's $(1964,2007)$ original model, this ichnofacies occurs between the Cruziana and Nereites ichnofacies on the external shelf to upper continental slope. The Zoophycos ichnofacies is dominated by Zoophycos, Phycosiphon, and Chondrites, although Nereites missouriensis, Planolites, Thalassinoides, and Cladichnus may also 

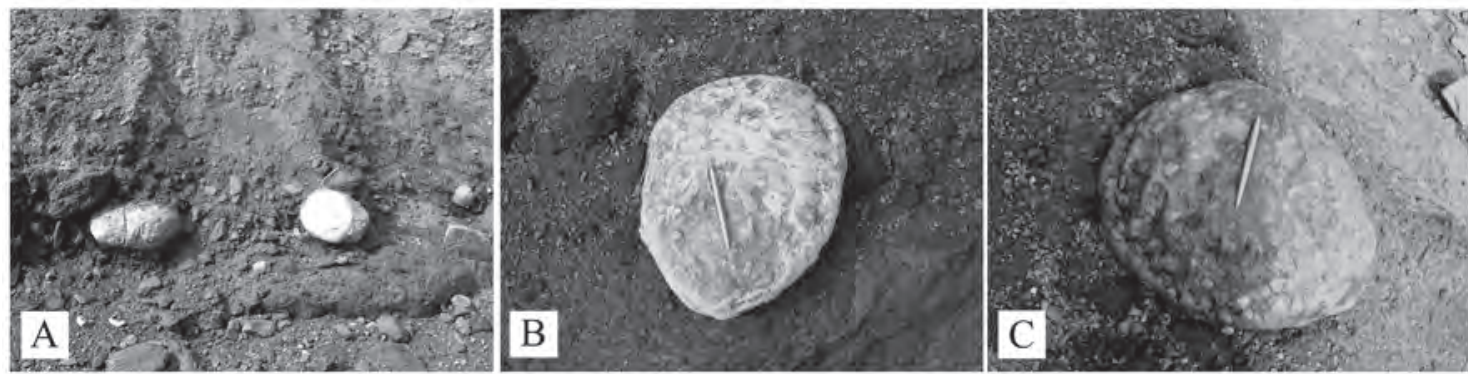

FIG. 3. A. In situ calcareous concretions containing radial trace fossils (Stelloglyphus llicoensis isp. nov.); B, C. In situ ellipsoidal concretion showing B, top surface with radial downward-curving tunnels and C, (turned around) bottom surface with tunnels in cross-section.

be present. In general, the presence of Zoophycos and Chondrites indicates sediments poor in oxygen, especially where occasional turbidity currents occur (Buatois and Mángano, 1992) or where there is a high input of nutrients (Buatois and López Angriman, 1991). However, in higher diversity assemblages such as the one described here, these traces usually occupy deeper tiers where sediment could be poor in oxygen, whereas the shallow tier and the sea floor may be well oxygenated (J.M. de Gibert, personal communication, 2007).

Ophiomorpha, Lockeia, and Rhizocorallium are more typical of the Cruziana ichnofacies (Buatois et al., 2002), which represents the lower shoreface to shelf environment. The observed trace fossil assemblage thus indicates a shelf to upper continental slope environment, which agrees with the benthic foraminiferal data. The presence of hummocky cross-lamination and (storm?) wave ripples in some beds supports an environment just above the storm wave base, i.e., the lower shoreface to continental shelf. The fining-upward sandstones and flute marks at the base of some beds, however, also indicate occasional turbidity currents, which are more typical of the continental slope.

The mudrocks containing the radial trace fossils form part of a generally fining-upward succession, so that they probably indicate deeper water than that represented by the underlying sandstonemudstone unit described above. A continental slope environment is therefore envisaged. The brecciated mudstones within this unit were probably deposited by debris flows triggered by storms or earthquakes on the steeper slopes.

\section{Systematic Ichnology}

Ichnogenus: Stelloglyphus Vialov, 1964.

Type ichnospecies: Stelloglyphus turkomanicus Vialov, 1964; Late Cretaceous (Turonian), Turkmenistan

Stelloglyphus llicoensis isp. nov. Figs. 4A-C and $5 \mathrm{~A}-\mathrm{C}$.

Type material: Holotype SGO.PI.6424 (Fig. 4A) and four paratypes SGO.PI.6425 (Figs. 4B and 5AC). Two further paratypes SMF XXX 849 and SMF XXX 850. SGO.PI is the collection prefix related to the Sección Paleontología, Museo Nacional de Historia Natural, Santiago, Chile; SMF refers to the Naturmuseum Senckenberg, Frankfurt am Main, Germany.

Other material examined: One specimen cut for examination (SGO.PI). Many more specimens, all from the area east of Llico, were observed at the type locality.

Derivation of the name: After the fishing village of Llico located just west of the ichnofossil type locality.

Type locality: The Pacific coast near the fishing village of Llico; Ranquil Formation, about $5 \mathrm{~km}$ west of the succession at Punta El Fraile, which has been dated as late Miocene to early Pliocene in age by Finger et al. (2007).

Occurrence: Concretions containing trace fossils of the new ichnospecies Stelloglyphus llicoensis were washed up on beaches east of Llico, between Estero Pajonal $\left(73^{\circ} 33^{\prime} 25^{\prime \prime} \mathrm{W}\right)$ and $\mathrm{La} \mathrm{Cal}$ $\left(73^{\circ} 31^{\prime} 05^{\prime \prime} \mathrm{W}\right)$. In situ occurrences were found at 73³3’00”'W (Figs. 2, 3). 


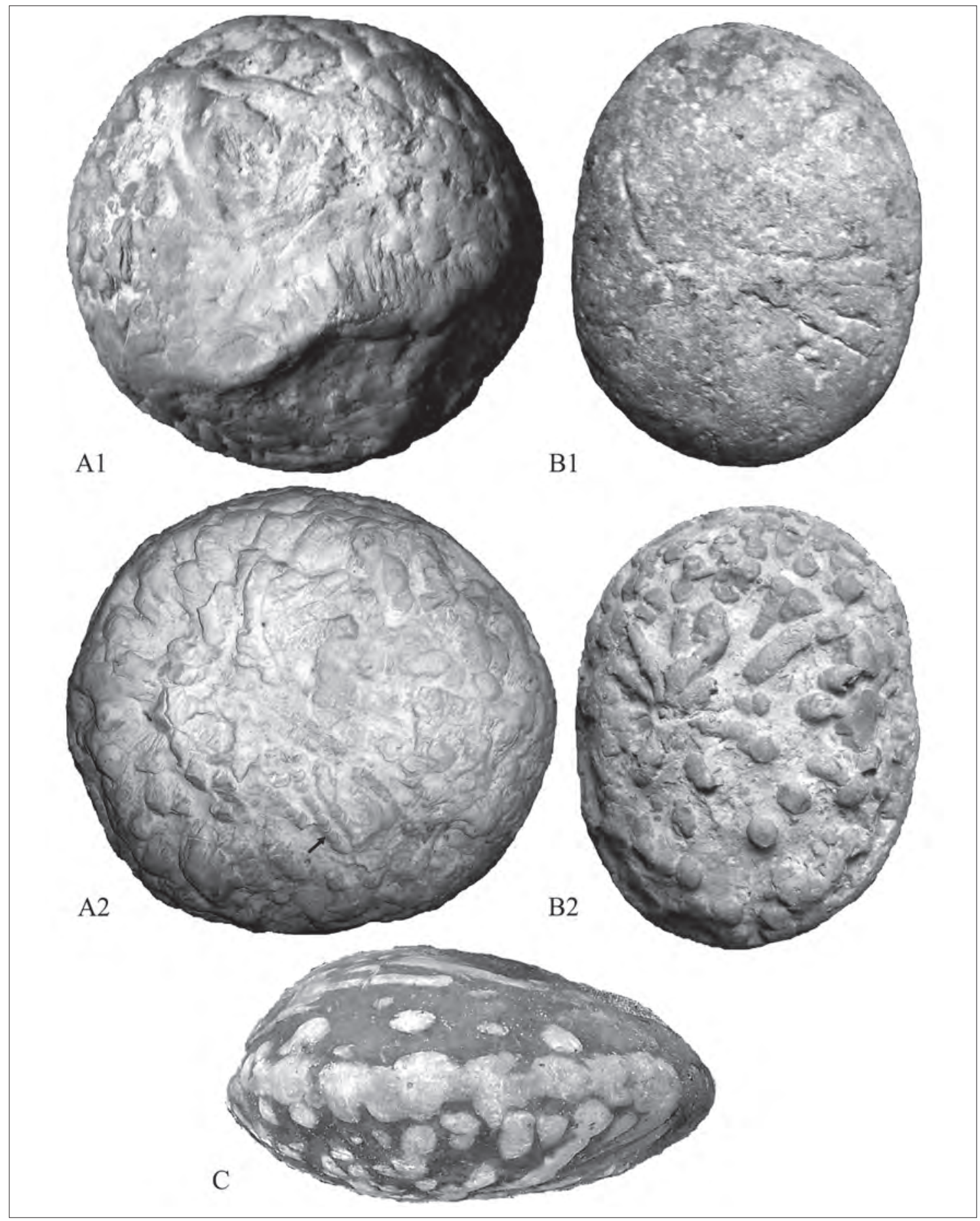

FIG. 4. Stelloglyphus llicoensis isp. nov. A1, A2. Discoidal concretion with holotype SGO.PI.6424, showing downward-curved radial tunnels. Note meniscate shapes (arrow) in some tunnels. A1, top, and A2, bottom views; B1, B2. Ellipsoidal concretion with paratype SGO.PI.6425a, showing central shaft and radial, downward-curving tunnels. Note double-ring structure and outwardwidening radial tunnels with smooth walls. Both rings of central shaft in some cases have a hard, protruding layer on their outside, possibly of organic origin. B1, top, and B2, bottom views; C. Lateral view of ring structure formed by fused radial tunnels about halfway from the base. This concretion was not recovered. 
Diagnosis: Multi-level, meniscate, rarely branched tunnels normally radiating and curving downward from a central shaft, but bottom tunnels in some cases also curve upward. Filling of tunnels different from surrounding sediment. Central shaft well developed, less than $10 \mathrm{~mm}$ in diameter, with distinct inner and outer rings sometimes separated by a hard, protruding layer.

Description: The concretions containing Stelloglyphus llicoensis are generally discoidal (Figs. 4A,
5C) to ellipsoidal (Figs. 2, 4B, 5A) and flattened along the bedding. The tops of the concretions are slightly cone- or dome-shaped, with flatter, less curved bases. The shapes of these concretions have clearly been controlled by the traces, because their outlines follow the curvature of the tunnels. Fifty-six measured concretions had long diameters $\left(D_{l}\right)$ ranging in size from 150-400 $\mathrm{mm}$, compared to $140-310 \mathrm{~mm}$ for the intermediate diameters $\left(D_{i}\right)$ and $80-180 \mathrm{~mm}$ for the short (vertical) diameters

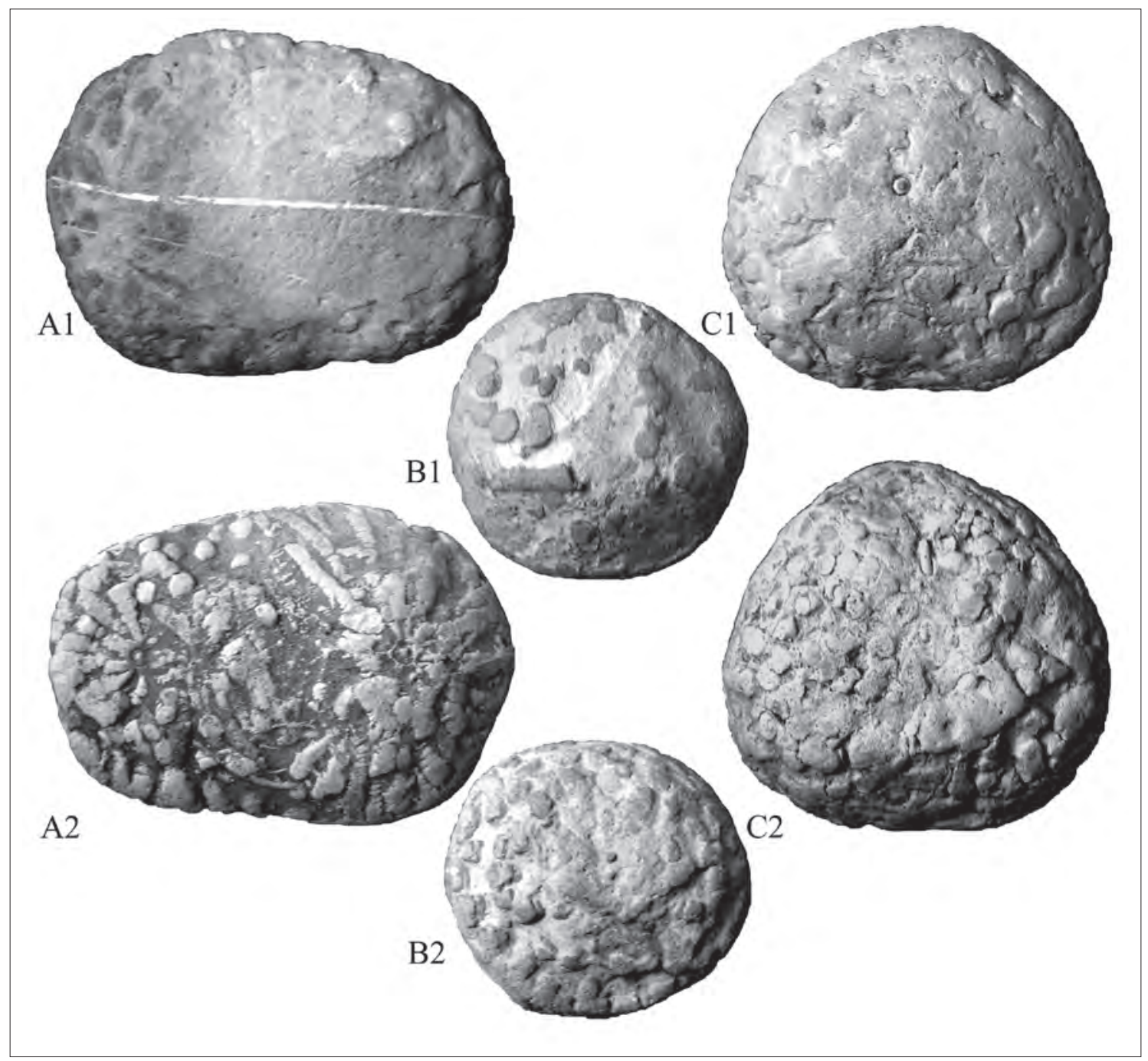

FIG. 5. Stelloglyphus llicoensis isp. nov. A1, A2. Paratype SGO.PI.6425b, two specimens of Stelloglyphus llicoensis, with interpenetrating radial elements displaying distinctly segmented or meniscate structures. A2, top, and A1, bottom views; B1, B2. Paratype SGO.PI.6425c showing cross-sections of tunnels and central shaft. B1, bottom, and B2, top views; C1, C2. Paratype SGO. PI.6425d, showing rare case of elements radiating upward from central shaft and surrounded by vertical tunnels penetrating from the top of the structure. $\mathrm{C} 1$, top, and $\mathrm{C} 2$, bottom views. 
$\left(D_{s}\right)$, with means of $265( \pm 53.6) \mathrm{mm}, 225( \pm 40.2)$ $\mathrm{mm}$ and $123( \pm 24.5) \mathrm{mm}$, respectively. The mean $D_{l} / D_{l}$ ratio is $0.86( \pm 0.10)$ with a range of $0.65-1.00$, whereas the $D_{s} / D_{l}$ ratio is $0.47( \pm 0.10)$ with a range of $0.32-0.73$. Although this discoidal to ellipsoidal form is due to concretion-formation processes, it was clearly controlled by the burrow systems and thus reflects the actual geometry of the latter.

The trace fossil consists of a central shaft from which radiate single and occasionally branched, unwalled tubes (Fig. 4A2) with common constrictions and menisci, filled with light pinkish brown, very fine- to fine-grained, calcareous sandstone or limestone within a buff, muddy, calcareous matrix containing scattered sand grains. The central, vertical to oblique shaft measures less than $10 \mathrm{~mm}$ in diameter and has an inner and an outer ring (Figs. 4B2, 5A2, $5 \mathrm{C} 1$ ) separated by a groove, both rings being formed by micritic mud. This probably represents a lining or reinforcement of the shaft (J.M. de Gibert, personal communication, 2007). The two ring structures are occasionally separated by a hard, protruding layer up to $2 \mathrm{~mm}$ thick, with a similar layer lining the outside of the outer ring. The shafts penetrate to the base of the structures, although in some cases they cannot be distinguished from radial tunnels that become sub-vertical towards the base. In rare cases, there are two or more shafts within the same concretion, with their radial tunnels interpenetrating (Fig. 5A2). This does not necessarily mean that the two tunnel systems were formed simultaneously, however. A longitudinal section cut through one shaft shows a segmented structure, with the inner ring broken into fragments 2-5 $\mathrm{mm}$ long and arranged in an en echelon manner. This possibly resulted from compaction after the structure had been formed. The outer ring is vague in longitudinal section, being hardly discernible from the matrix.

The trace fossils are visible in the concretions only because of chemical and physical weathering enhancing their external features. Natural cracks exposing the interior of in situ concretions show only a very homogeneous mass of fine-grained sandy limestone, which is also the case with a laboratory-cut concretion containing clear Stelloglyphus llicoensis on its external surface.

The tubes radiating from the central shaft are in a stellate pattern, each with a diameter of 10 to 20 $\mathrm{mm}$ and circular to oval in cross-section. Their longitudinal shapes vary widely, from almost smooth to regularly pinching and swelling, and in some cases are distinctly segmented or meniscate (Fig. 5A), but in general they become wider away from the shaft. On the domed upper surface of the concretions, 20 to 40, partly overlapping stellate burrows may be preserved, curving downward along the surface but in some cases also laterally. About onethird to halfway from the top of the concretions, many stellate burrows fuse to form an irregular, ring-shaped structure around the perimeter (Fig. $4 \mathrm{C})$. The lower part of the concretions generally displays the tunnels in cross-section (Figs. 2, 5C2). However, in some cases the lowermost tunnels branch horizontally from the central shaft and curve upward, so that the basal and top sections may be similar in appearance (Fig. 4B).

Stelloglyphus llicoensis is associated with and in some cases reworked by Zoophycos, which reaches more than $500 \mathrm{~mm}$ in diameter and displays whorls with spreiten in cross-section, up to 3 storeys deep. Minute to mm-scale Chondrites also commonly occurs at the top of the Stelloglyphus llicoensis concretions, where they are locally associated with large, horizontal gastropod-produced trails.

A thin section of one of the concretions shows a very fine, unlaminated, micritic mudstone with spherical to slightly oval, calcareous framboidal structures $0.1-0.35 \mathrm{~mm}$ across, probably formed by microbes under reducing conditions. This supports the oxygen-poor environment (at least in the subsurface) suggested by the occurrence of the Zoophycos ichnofacies trace fossils in areas subject to occasional turbidity currents (Buatois and Mángano, 1992). These framboidal structures are surrounded and partially to completely replaced by calcite crystals somewhat larger than the matrix. Small, spherical carbon grains less than $0.01 \mathrm{~mm}$ across as well as larger, irregular flakes probably representing leaf or wood fragments are also common. All of these are partly replaced by calcite, which also forms veinlets up to $0.4 \mathrm{~mm}$ wide, consisting of larger crystals. An unbroken, delicate ostracod tests preserved within the thin section consists of slightly larger calcite crystals largely destroyed during polishing.

Remarks: Star-shaped or radial trace fossils may be caused by different behaviors - including resting traces, farming structures, feeding structures and possible nests - and have been described from a wide variety of environments (Grubić, 1970; Häntzschel, 1970; Bromley, 1990; Seilacher, 2007). These include ichnotaxa without a cen- 
tral shaft, such as Asteriacites Schlotheim, 1820 (Mángano et al., 1999), Asterosoma Otto, 1854 (Pervesler and Uchman, 2004), and Lorenzinia Gabelli, 1900 (Uchman, 1998), as well as ichnotaxa in which a central shaft or knob is present. Among the latter are Arenituba Stanley and Pickerill, 1995, Asterichnus Bandel, 1967, Atollites Maas, 1902, Capodistria Vialov, 1964 (Vialov, 1968), Dactyloidites Hall, 1886 (Fürsich and Bromley, 1985), Estrellichnus Uchman and Wetzel, 2001, Glockerichnus Pickerill, 1982 (Książkiewicz, 1977), Gyrophyllites Glocker, 1841 (Fischer-Ooster, 1858; Fürsich, 1974), Maiakarichnus Verde and Martínez, 2004, Phoebichnus Bromley and Asgaard, 1972, Sphaerichnus Fürsich, 1998 and Stelloglyphus Vialov, 1964 (Häntzschel, 1975).

Of those traces radiating from a central shaft, all except Dactyloidites, Maiakarichnus, Phoebichnus, Sphaerichnus and Stelloglyphus have tunnels, lobes, ridges or grooves developed essentially along the same horizontal plane, or curving upward towards the surface only at their extremities. The burrows described here do not form a ring structure on bedding surfaces, which is distinct from, for example, Estrellichnus jacaensis Uchman and Wetzel, 2001 or Capodistria vettersi Vialov, 1968 (Uchman and Wetzel, 2001).

Among those traces with multi-level radiating tunnels, only Dactyloidites and Stelloglyphus have characteristics similar to the new traces found at Llico, as discussed below. Maiakarichnus currani Verde and Martínez, 2004, recently described from the Late Miocene of Uruguay by these authors, is preserved in full relief as a subspherical chamber with numerous thin shafts radiating upward from its upper part and sides. It has been interpreted as a callianassid brood structure. Phoebichnus, with its type ichnospecies $P$. trochoides (Bromley and Asgaard, 1972), has been described from the Jurassic of Greenland and its occurrence elsewhere is restricted to a few other Mesozoic successions. It has a large central disc and double-walled tunnels radiating horizontally at different levels, containing bi-directional back-fill menisci. Related forms include Phoebichnus bosoensis Kotake, 2003, which derives from the Neogene, and Phoebichnus minor that occurs in the Cambrian (Li and Yuan, 1999). The monotypic ichnogenus Sphaerichnus, described from the Jurassic of India 'lacks any internal structure such as spreiten' (Fürsich, 1998).
The type ichnospecies of Dactyloidites, Dactyloidites bulbosus Hall, 1886 [=Dactyloidites asterioides (Fitch, 1850)] from the Early Cambrian of New York State, and other ichnospecies such as Dactyloidites cabanasi, which is a stellate form with 4-6 broad, leaf-shaped radial tunnels around a central shaft (Vintaned et al., 2006), are restricted to one bedding plane. Some of the better known ichnospecies like $D$. ottoi and $D$. peniculus do not occur only in a single plane, but are multitiered and resemble our new ichnospecies to a certain extent. However, because of their differences from the type ichnospecies, it is doubtful whether these two forms really belong within the ichnogenus Dactyloidites. Dactyloidites ottoi Geinitz, 1849 is the type ichnospecies of Haentzschelinia Vialov, 1964, a placement regarded as appropriate by Seilacher (2007) and followed here, and we regard D. peniculus as being closer to Stelloglyphus llicoensis than to Dactyloidites asterioides. However, a revision of the ichnogenus Dactyloidites is beyond the scope of this work.

Stelloglyphus llicoensis differs widely from Haentzschelinia ottoi, which is characterized by protrusive spreiten (Gibert et al., 1995). Although it superficially resembles Dactyloidites peniculus D'Alessandro and Bromley, 1986, from the Pleistocene of southern Italy (D'Alessandro and Bromley, 1986; Uchman and Pervesler, 2007), it differs from the latter through better defined lateral tunnels (some of which bifurcate in contrast to those of $D$. peniculus), in having non-symmetrical tunnels, and in that its tunnels generally do not curve upwards after reaching the distal part and thus do not produce a concave centre at the base. The latter feature was not observed in any of the more than 60 specimens examined by us. The tunnels are also much wider (10-20 mm) than those of D. peniculus $(5-6 \mathrm{~mm})$.

Stelloglyphus llicoensis also resembles some ichnospecies of Gyrophyllites (e.g., Fürsich, 1974; $\mathrm{Fu}, 1991)$ but differs from these in being tridimensional (Fig. 6). That is, while ichnospecies of Gyrophyllites are star-shaped planar constructions, specimens of Stelloglyphus llicoensis radiate in three dimensions. According to Fürsich (1974), Gyrophyllites may have several storeys, but each storey is restricted to a single bedding surface. However, individual branches of Gyrophyllites are leaf-shaped and contrast strongly with the tubes of S. llicoensis. Especially Gyrophyllites isp. from 


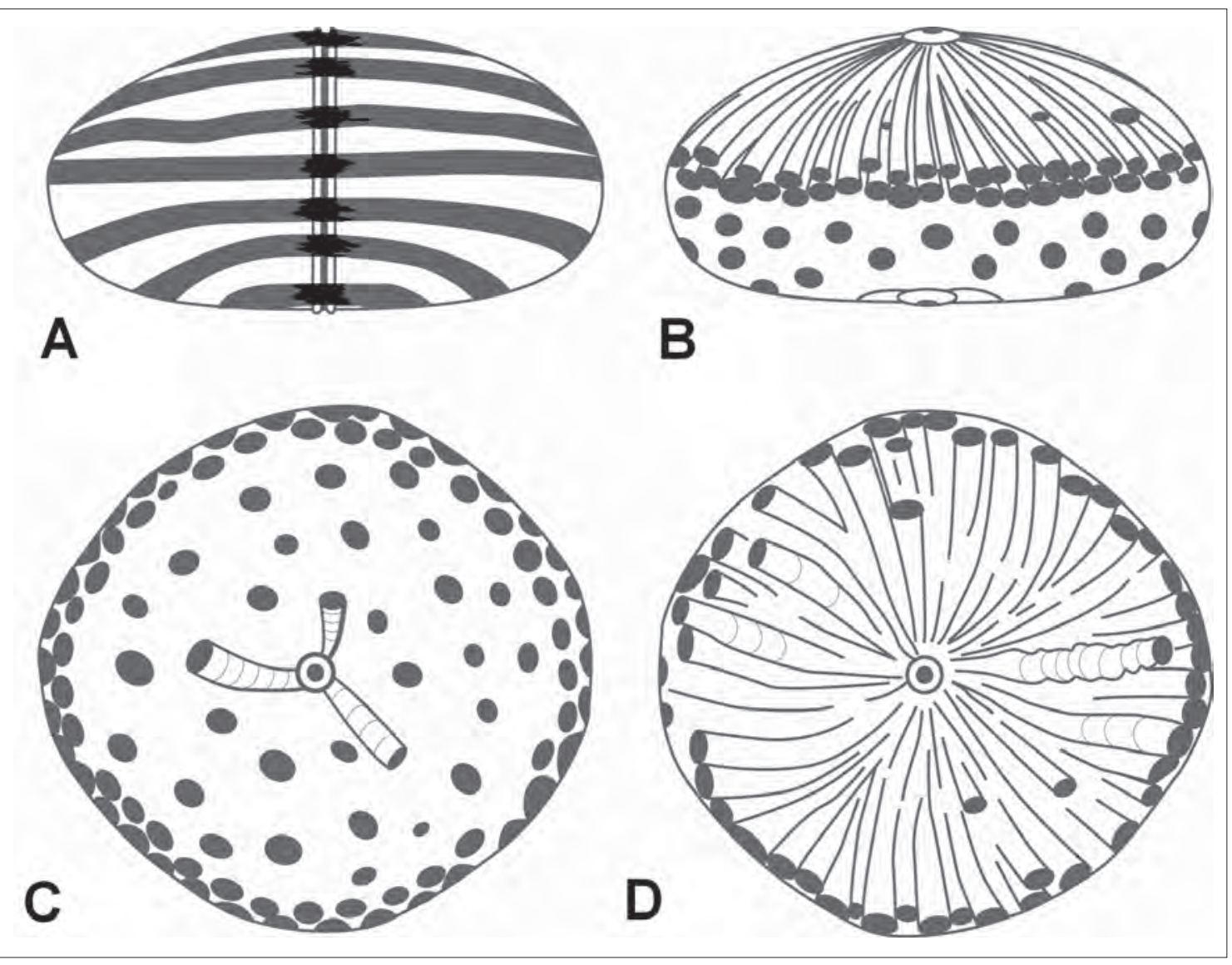

FIG. 6. Schematic reconstruction of Stelloglyphus llicoensis isp. nov. in a discoidal concretion. A. Vertical cross section through the axis of the trace fossil; B. Lateral view; C. Bottom view; D. Top view.

the Miocene flysch of Langun, Borneo (Fu, 1991, pl. 6 figs. A, B) looks similar. However, it seems to be the same specimen that was later figured as Stelloglyphus by Seilacher (2007, pl. 47). Some ichnospecies of Stelloglyphus (see Häntzschel, 1975, fig. 69) seem to be restricted to individual bedding planes, but published figures are rather poor. Others, like one example from the Miocene of Borneo (Seilacher, 2007, pl. 47 upper left) are very similar to the here described Stelloglyphus llicoensis in being multitiered but not restricted to individual bedding planes. Because of this we classify our new ichnospecies within the ichnogenus Stelloglyphus, although the tridimensional morphology can only be guessed at for the type ichnospecies (Häntzschel, 1975, fig. 69).

The ichnogenera Stelloglyphus, Gyrophyllites, and Dactyloidites are interpreted as fodinichnia, i.e., backfilled burrow-systems of stationary deposit-feeding organisms, and were grouped as 'gyrophyllitids' by Seilacher (2007). Consequently, Stelloglyphus llicoensis is here interpreted as a feeding burrow system. Fodinichnia commonly display active filling due to food processing and typically have unwalled burrows, which fit in with our observations (Buatois et al., 2002).

\section{Conclusions}

The radial trace fossil Stelloglyphus llicoensis occurs in an early Pliocene sedimentary succession rich in organic material, deposited in subtropical to tropical waters in an outer shelf to upper continental slope environment, in contrast to similar ichnospecies that occur in shallow water environments, e.g., Dactyloidites peniculus (D'Alessandro and 
Bromley, 1986), D. cabanasi (Vintaned et al., 2006) and Haentzschelinia ottoi (Gibert et al., 1995; Agirrezabala and Gibert, 2004). Turbidity currents occasionally disturbed the generally calm environment. The sediment pore-water was probably poor in oxygen, at least in the subsurface, as indicated by calcareous framboidal structures and preserved plant fragments. The trace fossil consists of a central, double-ringed shaft with single to branched, smooth to meniscate tunnels radiating downward from different levels. Only in rare cases do the basal radial elements curve slightly upward. Stelloglyphus llicoensis is interpreted as a backfilled burrow-system of a stationary deposit-feeding organism. The ichnofossil is associated with the Zoophycos ichnofacies, although it may also have some affinity with the Cruziana ichnofacies.

\section{Acknowledgements}

M. Dziggel (GeoForschungsZentrum Potsdam, Germany) produced the final version of figure 6 . This project was funded by Fondecyt 1010691 and Deutsche Forschungsgemeinschaft grants Ni699/4-1, which is gratefully acknowledged. The study was completed while JPLR held a fellowship at the Hanse Institute for Advanced Study in Delmenhorst, Germany and SNN was at GFZ Potsdam; the logistical and financial support of both institutions is greatly appreciated. Reviews by J. de Gibert, S. Palma, V. Pineda, L. Spalletti and an anonymous reviewer helped to improve the manuscript.

\section{References}

Agirrezabala, L.M.; Gibert, J.M. de, 2004. Paleodepth and paleoenvironment of Dactyloidites ottoi (Geinitz, 1849) from the Lower Cretaceous deltaic deposits (Basque-Cantabrian basin, west Pyrenees). Palaios 19: 276-291.

Aguirre, L. 1985. The southern Andes. In The Ocean Basins and Margins (Nairn, A.E.M.; Stehli, F.G.; Uyeda, S.; editors). The Pacific Ocean. Plenum Press 7a: 265-376. New York.

Bandel, K. 1967. Trace fossils from two Upper Pennsylvanian sandstones in Kansas. The University of Kansas, Paleontological Contributions 18: 1-13.

Bromley, R.G. 1990. Trace fossils: biology and taphonomy. Special Topics in Palaeontology 3: 280 p.

Bromley, R.G.; Asgaard, U. 1972. Notes on Greenland trace fossils. III. A large radiating burrow-system in Jurassic micaceous sandstones of Jameson Land, east Greenland. Gronlands Geologiske Undersogelse Rapport 49: 23-30.

Buatois, L.A.; Mángano, M.G. 1992. La oxigenación como factor de control en la distribución de asociaciones de trazas fósiles, Formación Kotick Point, Cretácico de Antártida. Ameghiniana 29: 69-84.

Buatois, L.A.; López Angriman, A.O. 1991. Ichnología de la Formación Whiskey Bay (Cretácico, Isla James Ross, Antártida): Implicancias paleoecológicas y paleoambientales. Ameghiniana 28: 75-88.

Buatois, L.A.; Mángano, M.G.; Aceñolaza, F.G. 2002. Trazas Fósiles: Señales de Comportamiento en el Registro Estratigráfico. Museo Paleontológico Egidio Feruglio, Chubut, Argentina: 382 p.

D’Alessandro, A.; Bromley, R.G. 1986. Trace fossils in Pleistocene sandy deposits from Gravina area, southern Italy. Rivista Italiana di Paleontologia e Stratigrafia 92: 67-102.

Encinas, A.; Le Roux, J.P.; Buatois, L.A.; Nielsen, S.N.; Finger, K.L.; Fourtanier, E.; Lavenu, A. 2006. Nuevo esquema estratigráfico para los depósitos mio-plioce-

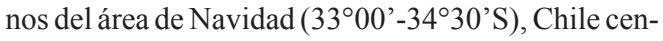
tral. Revista Geológica de Chile 33 (2): 221-246.

Finger, K.L.; Nielsen, S.N.; DeVries, T.J.; Encinas, A.; Peterson, D.E. 2007. Paleontologic evidence for sedimentary displacement in Neogene forearc basins of central Chile. Palaios 22: 3-16.

Fischer-Ooster, C.V. 1858. Die fossilen Fucoiden der Schweizer Alpen, nebst Erörterungen über deren geologisches Alter. Huber: 72 p. Bern.

Fitch,A. 1850. A historical, topographical and agricultural survey of the County of Washington. Transactions of the New York State Agricultural Society 9 (1849): 753-944.

Fu, S. 1991. Funktion, Verhalten und Einteilung fucoider und lophocteniider Lebensspuren. Courier Forschungsinstitut Senckenberg 135: 1-79.

Fürsich, F.T. 1974. Corallian (Upper Jurassic) trace fossils from England and Normandy. Stuttgarter Beiträge zur Naturkunde B13: 1-51.

Fürsich, F.T. 1998. Environmental distribution of trace fossils in the Jurassic of Kachch (western India). Facies 39: 46-53.

Fürsich, F.T.; Bromley, R.G. 1985. Behavioural interpretation of a rosetted spreite trace fossil: Dactyloidites ottoi (Geinitz). Lethaia 18: 199-207.

Gabelli, L. 1900. Sopra un interessante impronta medusoide. Il Pensiero Aristotelico nella Scienza Moderna, anno $\mathrm{I}^{\circ}$, fascicolo $\mathrm{II}^{\circ}$ : 75-79.

García, F. 1968. Estratigrafía del Terciario de Chile central. In Symposio Terciario de Chile, Zona Central (Cecioni, G.; editor). Editorial Andrés Bello: 25-58. Santiago.

Geinitz, H.B. 1849. Das Quadersandsteingebirge oder Kreidegebirge in Deutschland. Graz and Gerlach, Freiberg: $292 \mathrm{p}$.

Gibert, J.M. de; Martinell, J.; Doménech, R. 1995. The rosetted feeding trace fossil Dactyloidites ottoi (Geinitz) from the Miocene of Catalonia. Geobios 28: 769-776.

Glocker, F.E. 1841. Über die kalkführende Sandsteinfor- 
mation auf beiden Seiten der mittleren March, in der Gegend zwischen Kwassitz und Kremsier. Academia Caesarea Leopoldino-Carolina Germanica Naturae Curiosorum 19 (Supplement 2): 309-334.

Groves, L.T.; Nielsen, S.N. 2003. A new Late Miocene Zonaria (Gastropoda: Cypraeidae) from central Chile. The Veliger 46: 351-354.

Grubić, A. 1970. Rosetted trace fossils: a short review. In Trace fossils (Crimes, T.P.; Harper, J.C.; editors). Geological Journal, Special Issue 3: 185-188.

Hall, J. 1886. Note on some obscure organisms in the roofing slate of Washington County, New York. New York State Museum of Natural History, Annual Report 39: p. 160, pl. 11.

Häntzschel, W. 1970. Star-like trace fossils. In Trace fossils (Crimes, T.P.; Harper, J.C.; editors). Geological Journal, Special Issue 3: 201-214.

Häntzschel, W. 1975. Trace fossils and problematica. In Treatise on Invertebrate Paleontology, Part W Supplement 1 (Teichert, C.; editor). Geological Society of America and University of Kansas Press, Lawrence: 269 p.

Kennett, J.P.; Srinivasan, M.S. 1983. Neogene Planktonic Foraminifera: a Phylogenetic Atlas. Hutchinson Ross, Stroudsburg: $265 \mathrm{p}$.

Kotake, N. 2003. Ethologic and ecologic interpretation of complex stellate structures in Pleistocene deepsea sediments (Otadai Formation), Boso Peninsula, central Japan. Palaeogeography, Palaeoclimatology, Palaeoecology 192: 143-155.

Książkiewicz, M. 1977. Trace fossils in the flysch of the Polish Carpathians. Palaeontologia Polonica 36: 1-208.

Le Roux, J.P.; Elgueta, S. 1997. Paralic parasequences associated with Eocene sea-level oscillations in an active margin setting: Trihueco Formation of the Arauco Basin, Chile. Sedimentary Geology 110: 257-276.

Le Roux, J.P.; Nielsen, S.N.; Kemnitz, H.; Henríquez, A. 2008. APliocene mega-tsunami deposit and associated features in the Ranquil Formation, southern Chile. Sedimentary Geology 203: 164-180.

Le Roux, J.P.; Vargas, G. 2005. Hydraulic behavior of tsunami backflows: Insights from their modern and ancient deposits. Environmental Geology 49: 65-75.

Li, Y.; Yuan, J.L. 1999. Lower Cambrian trace fossils from the Mantou Formation of Huainan, Anhui. Acta Paleontologica Sinica 38: 114-124.

Maas, O. 1902. Über Medusen aus dem Solenhofer Schiefer und der unteren Kreide der Karpathen. Palaeontographica 48: 297-322.

Mángano, M.G.; Buatois, L.A.; West, R.R.; Maples, C.G. 1999. The origin and paleoecologic significance of the trace fossil Asteriacites in the Pennsylvanian of Kansas and Missouri. Lethaia 32: 17-30.

Nielsen, S.N.; Frassinetti, D. 2007a. The Miocene Volutidae (Gastropoda: Neogastropoda) from the Pacific coast of Chile. Journal of Paleontology 81: 82-102.
Nielsen, S.N.; Frassinetti, D. 2007b. The Miocene Architectonicidae (Gastropoda) of Chile. Paläontologische Zeitschrift 81: 291-303.

Nielsen, S.N.; Frassinetti, D.; Bandel, K. 2004. Miocene Vetigastropoda and Neritimorpha (Mollusca, Gastropoda) of Central Chile. Journal of South American Earth Sciences 7: 73-88.

Otto, E. von. 1854. Additamente zur Flora des Quadergebirges in Sachsen. Part 2. G. Mayer, Leipzig: 53 p.

Pervesler, P.; Uchman, A. 2004. Ichnofossils from the type area of the Grund Formation (Miocene, Lower Badenian) in northern Lower Austria (Molasse basin). Geologica Carpathica 55: 103-110.

Pickerill, R.K. 1982. Glockerichnus, a new name for the trace fossil ichnogenus Glockeria Książkiewicz, 1968. Journal of Paleontology 56: 816.

Pineda, V. 1986. Evolución paleogeográfica de la cuenca sedimentaria cretácico-terciaria de Arauco. In Geología y recursos minerales de Chile (Frutos, J.; Oyarzún, R.; Pincheira, M.; editors). Editorial de la Universidad de Concepción 1: 375-390.

Schlotheim, E.F. von. 1820. Die Petrefactenkunde auf ihrem jetzigen Standpunkte durch die Beschreibung seiner Sammlung versteinerter und fossiler Überreste des Thier und Pflanzenreiches der Vorwelt erläutert. Becker, Gotha: 437 p., 15 pl.

Seilacher, A. 1964. Sedimentological classification and nomenclature of trace fossils. Sedimentology 3: 256-263.

Seilacher,A. 2007. Trace Fossil Analysis. Springer Verlag, Berlin Heidelberg New York: 226 p.

Stanley, D.C.A.; Pickerill, R.K. 1995. Arenituba, a new name for the trace fossil ichnogenus Micatuba Chamberlain, 1971. Journal of Paleontology 69: 612-614.

Tavera, J. 1942. Contribución al estudio de la estratigrafía y paleontología del Terciaro de Arauco. Anales del Congreso Panamericano de Ingeniería de Minas y Geología No. 1, 2: 580-632. Santiago.

Uchman, A. 1998. Taxonomy and ethology of flysch trace fossils: A revision of the Marian Książkiewicz collection and studies of complementary material. Annales Societatis Geologorum Poloniae 68: 105218.

Uchman, A.; Pervesler, P. 2007. Palaeobiological and palaeoenvironmental significance of the Pliocene trace fossil Dactyloidites peniculus. Acta Palaeontologica Polonica 52: 799-808.

Uchman, A.; Wetzel, A. 2001. Estrellichnus jacaensis nov. igen., nov. isp.-A large radial trace fossil from Eocene flysch (Hecho Group, northern Spain). Geobios 34: 357-361.

Verde, M.; Martínez, S. 2004. A new ichnogenus for crustacean trace fossils from the Upper Miocene Camacho Formation of Uruguay. Palaeontology 47: 39-49.

Vialov, O.S. 1964. Zvezdchatye ieroglify iz Triasa severovostoka Sibiri [Star-shaped hieroglyphs from the Triassic of northeastern Siberia]. Akademija Nauk 
SSSR, Geologii i Geofiziki, Sibirskoe Otdelenie 5: 112-115.

Vialov, O.S. 1968. On star-shaped problematica (In Russian, English title). Ezheegodnik Vsesoyuznogo Paleontologiches-kiyego Obshchestva 18: 326-340.

Manuscript received: July 27, 2007; accepted: February 26, 2008.
Vintaned, J.A.G.; Liñán, E.; Mayoral, E.; Dies, M.E.; Gozalo, R.; Muñiz, F. 2006. Trace and soft body fossils from the Pedroche Formation (Ovetian, Lower Cambrian of the Sierra de Córdoba, S. Spain) and their relation to the Pedroche event. Geobios 39: 443-468. 